\title{
PENINGKATAN KEMAMPUAN BERINTERAKSI MELALUI ROLE PLAYING ANAK RETARDASI MENTAL DI SLB NEGERI SURAKARTA
}

\author{
Kliwon*1, Lia Ratih Nurhidayah ${ }^{2}$ \\ Poltekkes Kemenkes Surakarta Jurusan Terapi Wicara
}

\begin{abstract}
Background: The research purpose was determined the implementation of role playing to improve interaction ability of mental retardation students in SLB Negeri Surakarta. The researc was used quasi experiment with one group pre and posttest design. The research was conducted in SLB Negeri Surakarta on February 2018 to January 2019. Data collection method were used observation and interview. Methods: Research method was used role playing through the lecture, discussion, task, and direct practice. Data analysis technique was used bivarian analysis. Result: The research results were shown that the implementation of role playing able to improve the interaction ability of retardation students in SLB Negeri Surakarta. Conclusion: Have significant effect on interaction ability of retardation students in SLB Negeri Surakarta.
\end{abstract}

Keywords: Mental Retardatio, Role Playing, Interaction Ability

\section{PENDAHULUAN}

Anak merupakan dambaan semua orang yang ada didalam suatu keluarga. Setiap keluarga pasti menginginkan anaknya tumbuh dan berkembang dengan normal. Pertumbuhan yang diinginkan seperti sehat fisik, mental, kognitif dan sosial yang dapat berguna bagi nusa, bangsa dan keluarganya. Anak memang harus diperhatikan sejak dia didalam kandungan sampai dia menjadi dewasa. Anak yang lambat dalam perkembangannya, baik perkembangan sosial maupun kecerdasaannya disebut dengan anak keterbelakangan mental (Suyono, Ranuh, Soetjiningsih., 2016).

Keterbelakangan mental adalah suatu kondisi yang merupakan ketidak normalan fungsi kecerdasan yang berada dibawah rata-rata dengan ketidakmampuan untuk dirinya sendiri, yang muncul sebelum umur 18 tahun. Orang-orang yang mempunyai tingkat keterbelakangan rendah, memiliki perkembangan serta kecerdasan yang rendah dan mengalami kesulitan dalam proses belajar dan beradaptasi disekitar lingkungannya (Aden, 2010).

Anak retardasi mental $(\mathrm{RM})$ atau disebut juga tuna grahita mempunyai fungsi intelektual dibawah rata - rata (70) yang muncul bersamaan dengan kurangnya perilaku adaptif, ketidakmampuan beradaptasi dengan kehidupan sosial sesuai tingkat perkembangan dan budaya, awitannya sebelum usia 18 tahun (Wong 2004).

Menurut penelitian World Health Organization (WHO) tahun 2009, jumlah anak RM seluruh dunia adalah $3 \%$ dari total populasi. Tahun $2006-2007$ terdapat 80.000 lebih penderita RM di Indonesia. Jumlah ini mengalami kenaikan yang pesat pada tahun 2009, dimana terdapat 100.000 penderita. Pada tahun 2009 ini terjadi peningkatan sekitar $25 \%$ (Depkes RI 2009). Prevalensi 
retardasi mental sekitar $1 \%$ dalam satu populasi. Insiden tertinggi pada masa anak sekolah dengan puncak umur 10 sampai 14 tahun. Retardasi mental mengenai 1,5 kali lebih banyak pada laki-laki dibandingkan dengan perempuan (Marasmis 2004).

Perkembangan

keterampilan emosional dan sosial pada anak retardasi mental ringan dan sedang dapat dioptimalkan dengan menggunakan metode terapi bermain. Terapi bermain yang digunakan adalah yang melibatkan interaksi dengan orang lain. Bermain merupakan bagian integral dari masa anak-anak, suatu media unik sebagai sarana mengembangkan keterampilan bahasa ekspresif, keterampilan komunikasi, perkembangan emosional, keterampilan sosial, kemampuan membuat keputusan dan perkembangan kognisi pada anak (Tedjasaputra 2001).

Role playing juga disebut dengan bermain peran merupakan metode pembelajaran yang dapat mendorong peserta didik untuk memainkan peran yang berkaitan dengan pokok kajian yang disampaikan. Sosiodrama pada dasarnya mendramatisasikan tingkah laku dalam hubungannya dengan masalah sosial (Syaiful Bahri Djamarah dan Aswan Zain, 1996:101).

Peran peneliti bermain peran ini sebagai fasilitator, mendukung, dan mendorong terjadinya proses interaksi anak saat dilakukan permainan. Diharapkan dari penerapan role playing yang dilakukan secara berkelompok ini dapat meningkatkan kemampuan interpersonal anak, sehingga kemampuan interaksinya dapat meningkat.

\section{METODE PENELITIAN}

Penelitian ini menggunakan jenis penelitian eksperimen semu (quasi experiment) karena tidak terdapat pembatasan yang ketat terhadap randomisasi dan peneliti tidak memungkinkan untuk mengontrol semua variabel luar yang mempengaruhi pelaksanaan eksperimen. Sedangkan rancangan yang digunakan adalah one group pre and posttest design karena sebelum dan sesudah intervensi menggunakan satu kelompok yang sama (Taufiqurrahman, 2008).

Penelitian akan dilakukan di SLB Negeri Surakarta pada bulan Februari 2018 - Januari 2019. Populasi target dalam penelitian ini adalah anak retardasi mental di SLB Negeri Surakarta. Pada penelitian ini sampel yang digunakan adalah anak retardasi mental SLB Negeri Surakarta yang memenuhi kriteria restriksi. Teknik sampling dalam penelitian ini menggunakan NonProbability Sampling dan teknik sampling yang digunakan adalah sampling jenuh atau total sampling. Sampel penelitian terdiri dari satu kelompok yaitu kelompok eksperimen. Kelompok eksperimen terdiri dari subjek yang telah memenuhi kriteria yaitu pengasuh anak retardasi mental yang menjalani proses pretest, diberi pelatihan tentang cara meningkatkan kemampuan berinteraksi, dan dilakukan posttest.

Instrumen yang digunakan dalam penelitian ini yaitu tes, pedoman observasi dan pedoman wawancara.

Proses analisis data yang digunakan adalah analisis bivariat. Dalam penelitian ini pelatihan menggunakan metode role playing pada anak retardasi mental merupakan variabel bebas, sedangkan keterampilan sosialisasi adalah variabel terikat. 
Pengujian data untuk mengetahui ada tidaknya pengaruh role playing terhadap kemampuan interaksi pada anak retardasi mental menggunakan uji paired t-test.

\section{HASIL PENELITIAN}

Peningkatan Kemampuan Interaksi Sosial Siswa Retardasi Mental

Deskripsi pelaksanaan ekperimen ini meliputi pemberian tindakan atau perlakukan kepada subjek atau responden dengan pemberian permainan peran atau role playing berdasarkan desain eksperimen yang digunakan yaitu penelitian eksperimen semu (quasi experiment). Ketika proses pemberian tindakan atau treatment kepada subjek melalui pelatihan interaksi sosial. Peneliti melaksanakan proses ekperimen dengan harapan agar dapat melihat perubahan siswa dan mampu meningkatkan kemampuan interaksi sosial siswa melalui role playing.

Wolly and Wong tahun 2005 menyatakan bahwa perkembangan anak dengan kemampuan dalam interaksi sosial yang meliputi kontak sosial dan komunikasi kurang maka diperlukan adanya stimulasi atau perangsangan yang diberikan untuk merubah perilaku anak menjadi lebih baik. Salah satu stimulasi yang dapat diberikan kepada anak dapat melalui permainan. Hal ini juga diperkuat oleh Yuyun, 2010 dengan pernyataannya bahwa interaksi sosial dapat dicapai melalui suatu permainan, diantaranya permainan untuk meningkatkan motorik halus, motorik kasar, personal sosial dan bahasa. Untuk itu dalam penelitian ini dilaksanakan pelatihan atau treatment peningkatan kemampuan interaksi sosial melalui penerapan metode role playing, yang dilaksanakan dalam 3 (tiga) kali treatment.

Nilai rata-rata pada pelatihan/treatment pertama adalah 61,25 atau masuk dalam kategori kurang. Melihat nilai rata-rata ini maka perlu dilakukan kembali pelatihan peningkatan kemampuan berinteraksi melalui metode role playing pada siswa Retardasi Mental siswa SLB Negeri Surakarta untuk lebih mengoptimalkan kemampuan interaksi siswa .

Tabel 1. Rekapitulasi Kemampuan Interaksi Siswa SLB Negeri Surakarta pada Pelatihan I

\begin{tabular}{lcc}
\hline $\begin{array}{l}\text { Kriteria } \\
\text { Penilaian }\end{array}$ & $\begin{array}{c}\text { Jumlah } \\
\text { Siswa }\end{array}$ & Persentase \\
\hline Kurang & 16 & $80,00 \%$ \\
Cukup & 4 & $20,00 \%$ \\
Baik & 0 & $0 \%$ \\
Sangat Baik & 0 & $0 \%$ \\
\hline Jumlah & $\mathbf{2 0}$ & $\mathbf{1 0 0 \%}$ \\
\hline
\end{tabular}

Hasil rekapitulasi sebanyak 16 siswa $(80,00 \%)$. Siswa yang memiliki kemampuan interaksi cukup hanya 4 siswa $(20,00 \%)$. Tidak ada siswa yang memiliki kemampuan interaksi yang masuk dalam kriteria baik dan sangat baik. Masih rendahnya kemampuan interaksi siswa ini memerlukan pelatihan yang lebih intensif untuk meningkatkan kemampuan interaksi siswa SLB Negeri Surakarta.

Nilai rata-rata pada pelatihan/treatment kedua adalah 70,89 atau masuk dalam kategori cukup. Melihat nilai rata-rata ini maka perlu dilakukan kembali pelatihan peningkatan kemampuan berinteraksi melalui metode role playing pada siswa Retardasi Mental siswa SLB Negeri Surakarta untuk lebih mengoptimalkan kembali kemampuan interaksi siswa. 
Tabel 2. Rekapitulasi Kemampuan Interaksi Siswa SLB Negeri Surakarta pada Pelatihan II

\begin{tabular}{lcc}
$\begin{array}{l}\text { Kriteria } \\
\text { Penilaian }\end{array}$ & $\begin{array}{c}\text { Jumlah } \\
\text { Siswa }\end{array}$ & Persentase \\
\hline Kurang & 9 & $45,00 \%$ \\
Cukup & 8 & $40,00 \%$ \\
Baik & 3 & $15,00 \%$ \\
Sangat Baik & 0 & $0,00 \%$ \\
\hline Jumlah & $\mathbf{2 0}$ & $\mathbf{1 0 0 \%}$ \\
\hline
\end{tabular}

Pada pelatihan II ini siswa yang memiliki kemampuan interaksi yang kurang sebanyak 9 (45,00\%). Siswa yang memiliki kemampuan interaksi cukup hanya 8 siswa $(40,00 \%)$. Siswa yang memiliki kemampuan interaksi baik sebanyak 3 siswa $(15,00 \%)$. Peningkatan kemampuan interaksi siswa ini menunjukkan pelatihan yang menerapkan metode role playing mampu meningkatkan kemampuan interaksi siswa SLB Negeri Surakarta. Untuk lebih mengoptimalkan kemampuan interaksi siswa, maka dilanjutkan dengan treatment atau pelatihan III.

$$
\text { Nilai rata-rata pada }
$$

pelatihan/treatment ketiga adalah 79,46 atau masuk dalam kategori cukup. Melihat nilai rata-rata ini telah terjadi peningkatan kemampuan berinteraksi melalui metode role playing pada siswa Retardasi Mental siswa SLB Negeri Surakarta.

Tabel 3. Rekapitulasi Kemampuan Interaksi Siswa SLB Negeri Surakarta pada Pelatihan III

\begin{tabular}{lcc}
\hline $\begin{array}{l}\text { Kriteria } \\
\text { Penilaian }\end{array}$ & $\begin{array}{c}\text { Jumlah } \\
\text { Siswa }\end{array}$ & Persentase \\
\hline Kurang & 1 & $5,00 \%$ \\
Cukup & 8 & $40,00 \%$ \\
Baik & 11 & $55,00 \%$ \\
Sangat Baik & 0 & $0,00 \%$ \\
\hline Jumlah & $\mathbf{2 0}$ & $\mathbf{1 0 0 \%}$ \\
\hline
\end{tabular}

Pada pelatihan III ini siswa yang memiliki kemampuan interaksi yang kurang hanya 1 siswa $(5,00 \%)$. Siswa yang memiliki kemampuan teraksi cukup hanya 8 siswa $(40,00 \%)$. Siswa yang memiliki kemampuan interaksi baik sebanyak 11 siswa (55,00\%). Peningkatan kemampuan interaksi siswa ini menunjukkan keberhasilan pelatihan yang menerapkan metode role playing dalam meningkatkan kemampuan interaksi siswa SLB Negeri Surakarta.

Keberhasilan peningkatan kemampuan interaksi siswa retardasi mental SLB Negeri Surakarta dapat dilihat dari peningkatan nilai rata-rata dari setiap pelatihan, yaitu dari 61,25 pada pelatihhan pertama, kemudian naik menjadi 70,89 ada pelatihan kedua dan akhirnya meningkat lagi menjadi 79,46 pada pelatihan ketiga. Peningkatan ini menunjukkan keberhasilan penerapan metode role playing untuk meningkatkan kemampuan interaksi sosial siswa dengan retardasi mental di SLB Negeri Surakarta tahun pelajaran 2018/2019.

Soetjiningsih (1995) menyebutkan bahwa stimulasi adalah perangsangan yang datangnya dari lingkungan di luar individu anak. Anak yang lebih banyak mendapat stimulasi cenderung lebih cepat berkembang. Stimulasi juga berfungsi sebagai penguat (reinforcement). Memberikan stimulasi yang berulang dan terus-menerus pada setiap aspek perkembangan anak berarti telah memberikan kesempatan pada anak untuk tumbuh dan berkembang secara optimal (Nursalam, dkk, 2005).

Peningkatan interaksi sosial dengan pemberian stimulasi bermain peran atau role playing pada responden perlakuan mengalami peningkatan interaksi sosial pada pemberian 3 kali treatment, hal ini 
disebabkan responden mulai memahami cara permainan, beradaptasi bermain secara kelompok dan saling memahami karakter teman sepermainannya. Tetapi ada ada beberapa responden didapatkan tidak ada perubahan positif terhadap interaksi sosial setelah diberikan stimulasi bermain pran walaupun sudah diberikan sebanyak 3 kali. Hal ini kemungkinan disebabkan oleh riwayat kesehatan pada beberapa responden yaitu ada responden yang pernah didiagnosis meningitis pada usia 2 tahun dan seringnya menderita kejang-kejang sampai usia 5 tahun. Kejang demam dapat menyebabkan perubahan elektron pada otak sehingga perkembangan anak mengalami keterlambatan, begitu pula dengan meningitis, jika otak mengalami infeksi maka terjadi ganguan perkembangan seluruhnya mengingat otak merupakan pusat koordinasi seluruh oragan tubuh. Oleh karenanya dibutuhkan kesabaran dan waktu yang lebih lama untuk pemberian stimulasi dalam meningkatkan interaksi sosialnya pada rsponden tersebut. Tidak hanya kemampuan menerima stimulasi tersebut ada pada individu responden tetapi dari luar individu juga sangat penting. Penerimaan stimulasi yang diberikan oleh lingkungan di luar responden, jika dilakukan terus menerus dapat meminimalkan kerusakan interaksi social. Diperlukan keterlibatan guru pengajar dan orang tua.

Peningkatkan interaksi sosial pada murid SLB Negeri Surakarta sudah diupayakan untuk ditingkatkan yaitu dengan memberikan mata pelajaran pendidikan jasmani, olahraga dan kesehatan serta mata pelajaran seni budaya dan ketrampilan yang mengacu pada kurikulum. Sedangkan bentuk permainan yang diberikan pada siswa
SLB Negeri Surakarta meningkatkan interaksi sosial sebatas permainan motorik kasar misalnya bermain volley, bola. Pemberian mata pelajaran pendidikan jasmani, olahraga dan kesehatan dan permainan dilaksanakan tiap hari jumat.Jika hal tersebut diperhatikan maka dapat meminimalkan kerusakan interaksi social pada siswa retardasi mental SLB Negeri Surakarta.

\section{Pengaruh Metode Role Playing terhadap Kemampuan Interaksi Sosial Siswa Retardasi Mental}

Pengujian kelompok siswa yang mendapatkan perlakuan dengan metode role playing dalam pelatihan untuk meningkatkan kemampuan interaksi sosial akan memiliki skor rata-rata yang lebih tinggi dibandingkan dengan pelatihanpelatihan sebelumnya dengan menerapkan metode role playing.

Tabel 4. Uji Paired t-test

\begin{tabular}{lccc}
\hline Variabel & t-hitung & Sig. & $\begin{array}{c}\text { Level of } \\
\text { significant }\end{array}$ \\
\hline $\begin{array}{l}\text { Pre test \& } \\
\text { Post test }\end{array}$ & $-15,791$ & 0,000 & 0,05 \\
$\mathbf{N}: \mathbf{2 0}$ & & & \\
\hline
\end{tabular}

Sumber : Data Primer Diolah, 2018

Hasil uji Paired Sample t-test diperoleh signifikansi $=0,000$ kurang dari taraf signifikan $(\alpha)=0,05$ artinya ada perbedaan pengaruh yang signifikan antara rata-rata nilai sebelum perlakuan dengan rata- rata nilai sesudah perlakuan. Pada tabel $\mathrm{t}$ diperoleh $\mathrm{t}$ hitung negatif, yaitu $-15,791$ yang artinya rata-rata sebelum perlakuan lebih rendah dari pada rata-rata sesudah masing-masing treatment. Sehingga dapat disimpulkan terjadi peningkatan kemampuan interaksi sosial siswa retaardasi mental SLB Negeri 
Surakarta dari pelatihan ke pelatihan berikutnya.

Berdasarkan hasil analisis uji peningkatan kemampuan interaksi sosial di atas, maka hipotesis ini dapat diterima yang menyatakan bahwa melalui penerapan metode role playing mampu meningkatkan kemampuan berinteraksi siswa dengan retardasi mental di SLB Negeri Kota Surakarta, dapat diterima kebenarannya. Sehingga, dapat disimpulkan bahwa metode role playing dapat meningkatkan kemampuan interaksi sosial siswa retardasi mental SLB Negeri Surakarta.

Menurut penelitian yang dilakukan oleh Crick dan Dodge tahun 1994 disebutkan bahwa keterampilan pengolahan sosial-kognitif anak-anak dengan Retardasi Mental dengan fokus persepsi sosial dan generasi strategi, yang telah ditemukan sangat penting untuk memenuhi tantangan kelas sosial. Pada proses ini, persepsi sosial, mengacu pada kemampuan individu untuk menafsirkan atau "membaca" pesan sosial yang relevan dari orang lain. Hal ini dapat diberikan dalam bentuk permainan yang dapat meningkatkan interaksi sosial pada anak retardasi mental. Pesan-pesan ini, yang dikenal sebagai isyarat-isyarat sosial, yang terdiri dari rangsangan verbal dan nonverbal. Isyarat sosial dapat mencakup tindakan fisik, kata-kata, ekspresi wajah, nada suara, dan bahasa tubuh yang menceritakan tentang perilaku orang lain, perasaan, dan niat melalui bentuk permainan yang diberikan minimal delapan kali (Lefferd, 2010).

Stimulasi role playing yang dilakukan sampai 3 kali dimana permainan tersebut dilakukan oleh 3-5 orang, menunjukkan suatu kebersamaan, saling bicara atau saling komunikasi serta dapat menimbulkan kegembiraan, pertikaian dan persaingan, ternyata antara kontak sosial dan komunikasi didapatkan perkembangan kontak sosial lebih baik dibandingkan komunikasi. Dalam melakukan permainan tersebut mereka masih membutuhkan arahan dan bimbingan dalam melaksanakan interaksi sosial.

\section{PEMBAHASAN}

Penerapan teknik untuk belajar anak seperti mendengar, berbicara atau mengolah kata ada banyak sekali. Anak akan semakin cepat menangkap stimulus atau respon-respon yang diberikan melalui sebuah permainan, seperti respon untuk perkembangan fisik, kognitif, moral, emosional, dansosial. Perkembangan fisik yang mencakup aspek tinggi badan, berat badan, proporsi, dan bentuk tubuh. Kognitif mencakup proses mental dan pikiran. Kemudian moral yang berkaitan dengan tanggapan anak terhadap aturanaturan. Lalu emosional dan sosial yang mencakup pengenalan anak terhadap perkembangan emosinya sendiri dan mencakup pengalaman anak terhadap lingkungannya dengan keluarga, teman sebaya, dan kelompok teman sebaya.

Kegiatan bermain yang dilakukan anak-anak khususnya anak retardasi mental bisa menjadi media untuk berkomunikasi dengan sekitarnya. Seperti contoh jenis permainan yang dapat digolongkan ke permainan aktif, yaitu role playing. Role playing merupakan salah satu jenis permainan yang dilakukan secara berpura-pura yang dahulu banyak dilakukan anak-anak. Permainan ini hampir sama dengan sosiodrama yang sama-sama pada permainan peran. Bedanya pada role playing ini lebih menekankan pada alat-alat permainan 
seperti dokter yang lengkap dengan peralatan dokternya. Permainan peran yang dilakukan akan meningkatkan interaksi anak dalam meningkatkan kemampuan komunikasinya terhadap lingkungan sekitarnya.

Permainan role playing yang diterapkan kepada anak autis dapat membawa kesenangan tersendiri untuk memberikan hiburan dan mengeksplore diri serta dapat mendukung setiap perkembangan yang dilaluinya, terlebih lagi ketika anak memasuki usia sekolah yang mudah tertarik dengan permainan. Maka dari itu, penerapan permainan role playing perlu diketahui seberapa besar pengaruhnya terhadap perkembangan anak retardari mental khususnya pada interaksi sosial yang dilakukannya.

Yuyun, 2010 mengatakan bahwa interaksi sosial dapat dicapai melalui suatu permainan, diantaranya permainan untuk meningkatkan motorik halus, motorik kasar, personal sosial dan bahasa melalui permainan ular tangga, dimana permainan tersebut dapat meningkatkan interaksi sosial yaitu permainan tersebut dilakukan oleh lebih dari 3-5 orang, menunjukkan suatu kebersamaan, saling bicara atau saling komunikasi serta dapat menimbulkan kegembiraan, pertikaian dan persaingan untuk memenangkannya.

Menurut penelitian yang dilakukan oleh Crick dan Dodge tahun 1994 disebutkan bahwa keterampilan pengolahan sosial-kognitif anak-anak dengan Retardasi Mental dengan fokus persepsi sosial dan generasi strategi, yang telah ditemukan sangat penting untuk memenuhi tantangan kelas sosial. Pada proses ini, persepsi sosial, mengacu pada kemampuan individu untuk menafsirkan atau "membaca" pesan sosial yang relevan dari orang lain. Hal ini dapat diberikan dalam bentuk permainan yang dapat meningkatkan interaksi sosial pada anak retardasi mental. Pesan-pesan ini, yang dikenal sebagai isyarat-isyarat sosial, yang terdiri dari rangsangan verbal dan nonverbal. Isyarat sosial dapat mencakup tindakan fisik, kata-kata, ekspresi wajah, nada suara, dan bahasa tubuh yang menceritakan tentang perilaku orang lain, perasaan, dan niat melalui bentuk permainan yang diberikan minimal delapan kali (Lefferd, 2010).

Hal terpenting dari adanya penelitian ini adalah bagaimana membuat suatu permainan menyenangkan bagi anak autis, seperti halnya permainan yang sama untuk anak normal. Permainan apapun mungkin masih terasa asing dan tidak terasa alami bagi anak retardasi mental, tetapi masih bisa membuatnya menarik dan berguna jika mampu menemukan cara yang tepat. Selama dapat membantunya untuk memahami dunia sekitarnya maka tidak ada yang sia-sia. Pemahaman anak retardari mental terhadap apa yang dirasakan orang lain seperti empati sosial terasa sangat lemah. Oleh sebab itu, anak retardasi mental membutuhkan bantuan untuk memperoleh informasi terbaik melalui pancainderanya serta membuatnya bermakna dan selebihnya empati untuk berinteraksi sosial anak akan dapat meningkat.

\section{KESIMPULAN DAN SARAN}

Dalam Penerapan role playing mampu meningkatkan kemampuan interaksi sosial dan memiliki pengaruh yang signifikan terhadap kemampuan intraksi sosial siswa retardasi mental SLB Negeri Surakarta.

Dalam hal ini peneliti memberikan edukasi perlunya pemberian stimulasi untuk interaksi sosial pada setiap anak 
retardasi mental perlu adanya kerjasama antara guru dan orang tua dalam mengevaluasi tingkat perkembangan anak, perlu adanya penelitian yang lebih memodifikasi permainan terutama dalam peningkatan personal sosial, motorik halus dan bahasa, untuk anak retardasi mental perlu dilakukan stimulasi komunikasi yang bisa dilakukan dengan mendengarkan musik, pertahanan kontak mata, gerakan dan sentuhan kasih sayang sehingga dalam berinteraksi tidak mengalami hambatan sehingga untuk penelitian selanjunta sudah mendapatkan data yaitu tentang peningkatan komunikasi pada anak retardasi mental dengan stimulasi permainan seperti bermain peran, permainan halma, permainan monopoli dengan jumlah responden dan waktu yang lebih banyak.

\section{DAFTAR RUJUKAN}

Aden R. 2010. Seputar Penyakit \& Gangguan Lain Pada Anak. Yogyakarta: Hanggar Kreator.

Astuti, N. K 2010, Asas Pengajaran untuk Anak Tunagrahita, diakses 12 Februari 2018 pukul 19.55 WIB, http://www.balipost.co.id/mediadeta il.php?

module $=$ detailberitaming $\mathrm{a} \& \mathrm{kid}=1$

$3 \& i d=32524$

Maramis, 2004, Catatan Ilmu Kedokteran Jiwa, Airlangga University Press, Surabaya. Hal. 385

Rizka, 2009, Observasi Anak Tunagrahita, media release, 16 November, diakses hari 12 Februari 2018 pukul 19.45 WIB. rizkanury.blogspot.com/.../observasi -anak-tuna-grahita-sedang.html.

Slamet Santoso. 2010. Teori-teori Psikologi Sosial. Bandung : Refika aditama
Soetjiningsih, 1998, Tumbuh Kembang Anak, EGC, Jakarta. Hal. 105, 191.

Somantri, 2007, Psikologi Anak Luar Biasa, Refika Aditama, Bandung. Hal.103-105.

Suyono, Y., Ranuh, G., Soetjiningsih. 2016. Tumbuh Kembang Anak. Jakarta: EGC.

Syaiful Bahri Djamarah dan Aswan Zain. 2002. Strategi Belajar Mengajar. Jakarta: Rineka Cipta.

Taufiqurrahman. 2008. Pengantar Metodologi Penelitian untuk Ilmu Kesehatan. Surakarta: LPP UNS.

Tedjasaputra, M. S 2001, Bermain, Mainan, dan Permainan. Grasindo, Jakarta.

Wholly and Wong 2005, Nursing Care of Infants and Children 2, $6^{\text {th }} \mathrm{ed}$, MosbyInc. Missouri

Wong, D. L, 2004,Pedoman Klinis Keperawatan Pediatrik, EGC,Jakarta. Hal: 194-197, 651

Zuriah, N.2007. Metodologi Penelitian Sosial \& Pendidikan TeoriAplikasi. Jakarta: PT Bumi Aksara. 